\title{
Protective effects of sodium selenite supplementation against irradiation-induced damage in non-cancerous human esophageal cells
}

\author{
IRMA M. PUSPITASARI ${ }^{1,2}$, CHIHO YAMAZAKI ${ }^{1}$, RIZKY ABDULAH $^{2}$, MIRASARI PUTRI $^{1}$, \\ SATOMI KAMEO ${ }^{1}$, TAKASHI NAKANO ${ }^{3}$ and HIROSHI KOYAMA ${ }^{1}$ \\ ${ }^{1}$ Department of Public Health, Gunma University Graduate School of Medicine, Maebashi, \\ Gunma 371-8511, Japan; ${ }^{2}$ Department of Pharmacology and Clinical Pharmacy, Faculty of Pharmacy, \\ Universitas Padjadjaran, Bandung, West Java 45363, Indonesia; ${ }^{3}$ Department of Radiation Oncology, \\ Gunma University Graduate School of Medicine, Maebashi, Gunma 371-8511, Japan
}

Received August 1, 2015; Accepted October 7, 2016

DOI: $10.3892 / 01.2016 .5434$

\begin{abstract}
The administration of radioprotective compounds is one approach to preventing radiation damage in non-cancerous tissues. Therefore, radioprotective compounds are crucial in clinical radiotherapy. Selenium is a radioprotective compound that has been used in previous clinical studies of radiotherapy. However, evidence regarding the effectiveness of selenium in radiotherapy and the mechanisms underlying the selenium-induced reduction of the side effects of radiotherapy remains insufficient. To further investigate the effectiveness of selenium in radiotherapy, the present study examined the protective effects of sodium selenite supplementation administered prior to X-ray radiation treatment in CHEK-1 non-cancerous human esophageal cells. Sodium selenite supplementation increased glutathione peroxidase 1 (GPx-1) activity in a dose- and time-dependent manner. The sodium selenite dose that induced the highest GPx-1 activity was determined to be $50 \mathrm{nM}$ for $72 \mathrm{~h}$ prior to radiotherapy. The half-maximal inhibitory concentration of sodium selenite in CHEK-1 cells was $3.6 \mu \mathrm{M}$. Sodium selenite supplementation increased the survival rate of the cells in a dose-dependent manner and enhanced the degree of cell viability at $72 \mathrm{~h}$ post-irradiation $(\mathrm{P}<0.05)$. Combined treatment with $50 \mathrm{nM}$ sodium selenite and 2 gray (Gy) X-ray irradiation decreased the number of sub- $\mathrm{G}_{1}$ cells from 5.9 to $4.2 \%(\mathrm{P}<0.05)$ and increased the proportion of $\mathrm{G}_{1}$ cells from 58.8 to $62.1 \%$, compared with 2 Gy X-ray irradiation alone; however, this difference was not statistically significant
\end{abstract}

Correspondence to: Dr Hiroshi Koyama, Department of Public Health, Gunma University Graduate School of Medicine, 3-39-22 Showa Machi, Maebashi, Gunma 371-8511, Japan

E-mail: hkoyama@gunma-u.ac.jp

Key words: sodium selenite, radioprotection, X-ray irradiation, esophageal cells, apoptosis, irradiation-induced damage
$(\mathrm{P}=1.00)$. Western blot analysis revealed that treatment with 2 Gy X-ray irradiation significantly increased the expression levels of cleaved poly (ADP-ribose) polymerase (PARP; $\mathrm{P}<0.05)$. In addition, combined treatment with $50 \mathrm{nM}$ sodium selenite and 2 Gy X-ray irradiation reduced the expression levels of cleaved PARP protein, compared with 2 Gy X-ray irradiation alone; however, this reduction was not statistically significant $(\mathrm{P}=0.423)$. These results suggest that $50 \mathrm{nM}$ sodium selenite supplementation administered for $72 \mathrm{~h}$ prior to irradiation may protect CHEK-1 cells from irradiation-induced damage by inhibiting irradiation-induced apoptosis. Therefore, sodium selenite is a potential radioprotective compound for non-cancerous cells in clinical radiotherapy.

\section{Introduction}

Radiotherapy is one of the most common and effective treatments for cancer (1). Over $40 \%$ of patients with cancer require radiotherapy during the management of the disease (2). Although clinical radiotherapy treatment planning and delivery technologies have improved, the toxicity of radiotherapy to non-cancerous tissues and organs remains a problem $(2,3)$. Thus, radioprotective compounds are crucial in clinical radiotherapy (3), and the administration of radioprotective compounds has been suggested as an approach for preventing radiation-damage in normal tissues $(4,5)$.

Selenium is a trace element with a fundamental role in human biology (6). It detoxifies reactive oxygen species (ROS) produced by radiation treatment $(4,7)$. In human antioxidant systems, selenium acts in the form of selenocysteine, which is incorporated into various selenoproteins $(8,9)$. At least 25 selenoproteins have been identified in humans, including glutathione peroxidase (GPx), thioredoxin reductases, iodothyronine deiodinase and the selenoproteins P, W and R (10). Selenium exists in numerous chemical forms, of which the most studied are selenomethionine, sodium selenite, methylselenocysteine, 1,4-phenylenebis (methylene) selenocyanate and methylseleninic acid (9). Sodium selenite is the chemical form 
of selenium previously used in clinical studies of radiotherapy supplementation between 1987 and 2012 (7).

Despite having been previously used as a complementary medicine during clinical radiotherapy $(11,12)$, the effectiveness of selenium use in radiotherapy and the mechanisms underlying the effect of selenium in reducing the side effects of radiotherapy require further study (7). Schleicher et al (13) and Rodemann et al (14) performed in vitro studies of selenium and radiotherapy and identified that sodium selenite has potential as a protective agent for non-cancerous tissues during radiotherapy (15). However, the mechanisms underlying this protection have yet to be revealed. Diamond et al (16) demonstrated that low-level supplementation of culture media with sodium selenite significantly protected CHO-AA8 cells, a hamster ovary-derived cell line, from radiation-induced mutagenesis. Eckers et al (17) also reported that the overexpression of selenoprotein $\mathrm{P}$ suppressed radiation-induced ROS accumulation and protected normal human fibroblasts from radiation-induced toxicity. Tak et al (18) identified that, when U937 human leukemic monocyte lymphoma cells were exposed to $2 \mathrm{~Gy}$ of $\gamma$-radiation, a marked difference with respect to apoptotic features and mitochondrial function was observed between the cells that were and were not pre-treated with ebselen.

Further studies are required in order to determine the mechanisms underlying selenium-induced prevention of radiotherapy side effects, before it may be recommended as an adjuvant to cancer radiotherapy. Sodium selenite is the only chemical form of selenium that has previously been used in clinical studies for this purpose; therefore, the present study investigated the protective effects of sodium selenite supplementation on non-cancerous human esophageal cells, a cell type with high radiosensitivity, prior to X-ray irradiation.

\section{Materials and methods}

Cell culture. The CHEK-1 immortalized non-cancerous human esophageal cell line was provided by Dr H. Matsubara (Department of Academic Surgery, Chiba University, Japan) (19) and maintained in RPMI-1640 medium (Wako Pure Chemical Industries, Ltd., Osaka, Japan) supplemented with $10 \%$ fetal bovine serum (HyClone; GE Healthcare Life Sciences, Logan, UT, USA) and $1 \%$ penicillin-streptomycin (Gibco; Thermo Fisher Scientific, Waltham, MA, USA), and incubated at $37^{\circ} \mathrm{C}$ in a humidified chamber containing $5 \%$ $\mathrm{CO}_{2}$. The culture medium was replaced every 3 days and the cells were passaged on a weekly basis using a 1:5 splitting ratio.

Selenium supplementation. Sodium selenite (Sigma-Aldrich; Merck Millipore, Darmstadt, Germany) was the chemical form of selenium that was used for supplementation of the cell medium. The sodium selenite supplementation doses ranged from $0-200 \mathrm{nM}$, and the duration of incubation was 24-72 h, $18 \mathrm{~h}$ following initial cell seeding at a density of $1 \times 10^{6}$ cells in a $10 \mathrm{ml} / 10 \mathrm{~cm}$ culture dish or $2 \times 10^{3}$ cells $/ 50 \mu 1$ well. Supplementation with a dose of $50 \mathrm{nM}$ sodium selenite for $72 \mathrm{~h}$ prior to radiation treatment was used for the cell viability assay, cell cycle analysis and western blot analysis.
Irradiation. Irradiation was performed using an X-Ray irradiation machine (Titan-225S; Shimadzu Corporation, Kyoto, Japan) at a rate of $1.3 \mathrm{~Gy} / \mathrm{min}$. The dose of irradiation was 2 Gy based on the common fractionation dose for radiotherapy.

Protein extraction for GPX-1 activity assay and western blot analysis. CHEK-1 cells were supplemented with $50 \mathrm{nM}$ sodium selenite for $72 \mathrm{~h}$, washed twice with PBS and harvested by adding a solution of $1 \mathrm{mM}$ EDTA in PBS, then removing the cells from the culture dish using a cell scraper. Proteins were then extracted using a radioimmunoprecipitation assay buffer (Sigma-Aldrich; Merck Millipore) with a $10 \%$ protein inhibitor cocktail (Sigma-Aldrich; Merck Millipore). The protein concentrations were determined using a DC ${ }^{\mathrm{TM}}$ protein assay kit (Bio-Rad Laboratories, Inc., Hercules, CA, USA) following the method of Lowry et al (20). The extracted samples were stored at $-80^{\circ} \mathrm{C}$ until the time of analysis.

GPX-1 activity assay. The enzymatic activity of GPx-1 in CHEK-1 cell homogenates was determined using the method described by Paglia and Valentine (21), with certain modifications. Briefly, GPx-1 activity was indirectly monitored using spectrophotometric methods to observe the reduction of oxidized glutathione, using nicotinamide adenine dinucleotide phosphate (NADPH) as the reducing agent. GPx-1 activity was quantified by measuring the change in NADPH absorbance at $340 \mathrm{~nm}$ and was expressed as the change in NADPH absorbance ( $\triangle \mathrm{mM}$ NADPH) over time (min) and with various levels of protein $(\mathrm{mg})$ in the presence of the substrate tert-butyl hydroperoxide. The absorbance was recorded using a SpectraMax Plus 384 microplate reader (Molecular Devices, LLC, Sunnyvale, CA, USA).

Cytotoxicity assay. The cytotoxicity of sodium selenite in CHEK-1 cells was examined with various concentrations of sodium selenite $(0-8 \mu \mathrm{M})$ using a colorimetric assay. Briefly, cells $\left(2 \times 10^{3}\right.$ in $50 \mu \mathrm{l} /$ well $)$ were seeded into 96 -well plates. Sodium selenite solutions were added $18 \mathrm{~h}$ following the initial cell seeding, and the cells were then incubated for $72 \mathrm{~h}$ at $37^{\circ} \mathrm{C}$ in a humidified chamber containing $5 \% \mathrm{CO}_{2}$. The cell proliferation rate and half-maximal inhibitory concentration $\left(\mathrm{IC}_{50}\right)$ were then determined using a Cell Counting kit-8 (Dojindo Molecular Technologies, Inc., Kumamoto, Japan) according to the manufacturer's protocol. The absorbance was measured at a wavelength of $450 \mathrm{~nm}$ using a SpectraMax Plus 384 microplate reader. The data was analyzed using linear regression analysis.

Clonogenic assay. The survival of the cells post-irradiation was investigated by conducting clonogenic and cell viability assays. To conduct the clonogenic assay, the CHEK-1 cell media was supplemented with various concentrations of sodium selenite $(0-200 \mathrm{nM})$ for $72 \mathrm{~h}$ from $18 \mathrm{~h}$ following the initial seeding, and were then irradiated with 2 Gy X-ray radiation. Immediately following irradiation, the cells $(500$ cells $/ 4 \mathrm{ml}$ medium) were seeded in Falcon $25 \mathrm{~cm}^{2}$ tissue culture flasks. Following 14 days of culture at $37^{\circ} \mathrm{C}$, the cells were washed once with PBS, fixed with $99.5 \%$ ethanol and stained with $0.5 \%$ crystal violet in $\mathrm{H}_{2} \mathrm{O}$ :methanol (1:1) for $30 \mathrm{~min}$ at room temperature. The cells were then washed with tap water and 

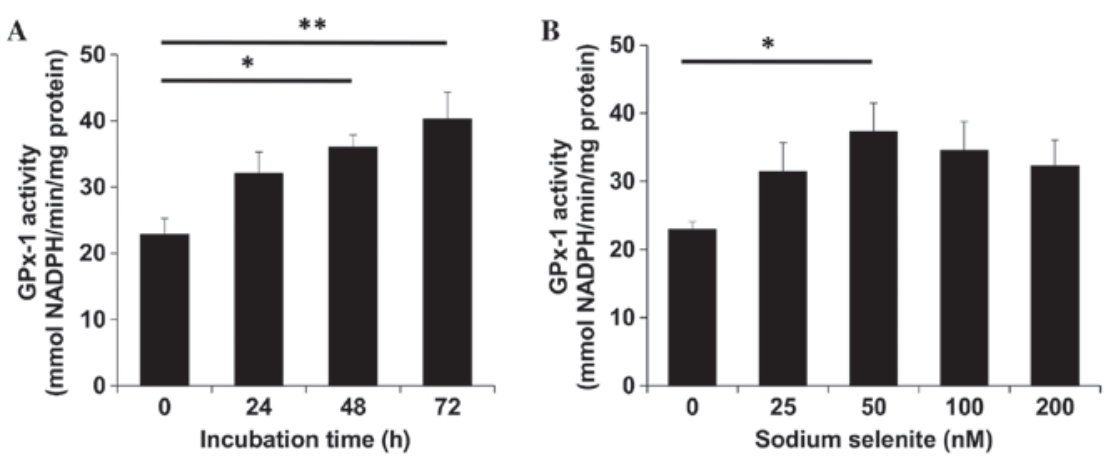

Figure 1. GPx-1 activity is increased in a dose- and time-dependent manner following sodium selenite supplementation. (A) A $50 \mathrm{nM}$ sodium selenite supplementation increased GPx-1 activity in a time-dependent manner. (B) Sodium selenite supplementation for $72 \mathrm{~h}$ increased GPx-1 activity in a dose-dependent manner. The results are presented as the mean \pm standard error of the mean from three independent experiments. ${ }^{*} \mathrm{P}<0.05$; ${ }^{* *} \mathrm{P}<0.01$. GPx-1, glutathione peroxidase 1.

air-dried. The total number of colonies containing $>50$ cells were counted using a binocular light microscope (Olympus Corporation, Tokyo, Japan). Following the counting of the colonies, the plating efficiency (PE) and survival fraction (SF) were calculated using the following equations $(22,23)$.

$$
\begin{gathered}
\mathrm{PE}=\frac{\text { Number of colonies formed }}{\text { Number of cells seeded }} \times 100 \% \\
\mathrm{SF}=\frac{\text { Number of colonies formed post irradiation }}{\text { Number of cells seeded } \mathrm{PE}} \times 100 \%
\end{gathered}
$$

Cell viability assay. To observe cell viability post-irradiation, CHEK-1 cells $\left(2 \times 10^{3}\right.$ in $50 \mu \mathrm{l} /$ well $)$ were seeded in 96-well plates. Sodium selenite $(50 \mathrm{nM})$ solution was added at $18 \mathrm{~h}$ following initial cell seeding, and the cells were incubated for $72 \mathrm{~h}$ prior to irradiation. Post-irradiation cell viability was examined every hour for $72 \mathrm{~h}$ using a Cell Counting kit-8, according to the manufacturer's protocol. The absorbance was measured at a wavelength of $450 \mathrm{~nm}$ using a SpectraMax Plus 384 microplate reader.

Cell cycle analysis. Detached and attached cells were collected at the end of each post-irradiation time point (24, 48 and $72 \mathrm{~h}$ ). Detached cells were collected from the medium. Attached cells were collected by adding a TrypLE ${ }^{\mathrm{TM}}$ Express solution (Thermo Fisher Scientific, Inc.) to attached cells and incubating at $37^{\circ} \mathrm{C}$ in a humidified chamber containing $5 \% \mathrm{CO}_{2}$ until the cells had detached. Detached and attached suspension cells were centrifuged at $168 \mathrm{x} g$ for $4 \mathrm{~min}$ at room temperature, the supernatant was removed and cells were washed twice with ice-cold PBS. The cells were fixed with $70 \%$ cold ethanol and stored at $-20^{\circ} \mathrm{C}$ until the time of analysis (1-4 days). On the day of analysis, the cells were washed with PBS, stained with $0.05 \mathrm{mg} / \mathrm{ml}$ of propidium iodide solution (Sigma-Aldrich, St. Louis, MO, USA) with $0.002 \mathrm{mg} / \mathrm{ml}$ RNAse (Wako Pure Chemical Industries, Ltd., Osaka, Japan) and incubated at room temperature for $30 \mathrm{~min}$. The DNA content was analyzed using fluorescence-activated cell sorting (FACSCalibur ${ }^{\mathrm{TM}}$; BD Biosciences, San Jose, CA, USA).

Western blot analysis. Total proteins were extracted from the cells and measured following sodium selenite supplementation at $72 \mathrm{~h}$ post-irradiation. Protein $(30 \mu \mathrm{g})$ samples were subjected to electrophoresis on a 5-20\% SuperSep ${ }^{\mathrm{TM}}$ Ace Ready Gel (Wako Pure Chemical Industries, Ltd., Osaka, Japan) and electrotransferred to a nitrocellulose membrane (GE Healthcare Life Sciences, Chalfont, UK). Prior to antibody treatment, the membrane was blocked with $5 \% \mathrm{w} / \mathrm{v}$ non-fat dry milk in a solution of $1 \mathrm{X}$ Tris-buffered saline and $0.1 \%$ polysorbate 20 by agitating for $45 \mathrm{~min}$ at room temperature. The protein levels were analyzed by incubating with (ADP ribose) polymerase (PARP) polyclonal antibody (Cell Signaling Technology, Inc., Danvers, MA, USA; cat. no. 9542; dilution 1:1,000) at $4{ }^{\circ} \mathrm{C}$, overnight. A horseradish peroxidase-conjugated donkey anti-rabbit IgG secondary antibody (GE Healthcare Life Sciences; cat. no. NA934; dilution 1:10,000) was used by incubating with gentle agitation for $90 \mathrm{~min}$ at room temperature. Protein bands were detected using an enhanced chemiluminescence detection system (GE Healthcare Life Sciences). A mouse anti-GAPDH antibody (cat. no. MAB374; Abcam, Cambridge, UK; dilution 1:500) served as the loading control. Scanning densitometry was performed using Image Quant LAS 4000 (Amersham, Buckinghamshire, UK) and the autoradiographs were quantified using ImageJ software version 1.50a (National Institutes of Health, Bethesda, MD, USA).

Statistical analysis. The data were presented as the mean \pm standard error from three independent experiments. The differences between multiple variables were analyzed by one-way analysis of variance and the Bonferroni pairwise comparison was used for post-hoc analysis. All statistical analyses were performed using the EZR (Easy R) statistical software program, an open-source statistical software program which is based on $R$ and $\mathrm{R}$ commander version 2.5.5 (24). $\mathrm{P}<0.05$ was considered to indicate a statistically significant difference.

\section{Results}

Sodium selenite increases GPX-1 activity. In CHEK-1 cells, sodium selenite supplementation was observed to increase GPx-1 activity in a dose- and time-dependent manner (Fig. 1). A previous study reported that $50 \mathrm{nM}$ sodium selenite was used as a supplementation dose in primary keratinocytes prior to UV radiation treatment (25). In the present study, when $50 \mathrm{nM}$ sodium selenite solution was administered to 


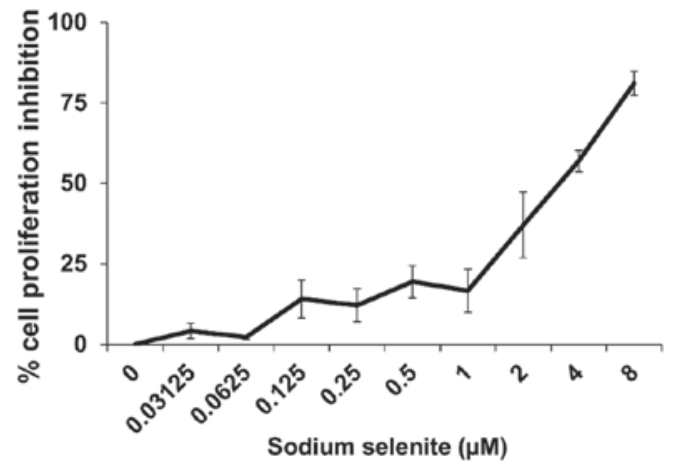

Figure 2. The $\mathrm{IC}_{50}$ of sodium selenite in CHEK-1 cells was $3.6 \mu \mathrm{M}$. $\mathrm{IC}_{50}$ was determined by linear regression analysis. The value was estimated by using the equation $\mathrm{y}=\mathrm{ax}+\mathrm{b}, \mathrm{IC}_{50}=(50-\mathrm{b}) / \mathrm{a}$. The results are presented as the mean \pm standard error of the mean from three independent experiments. $\mathrm{IC}_{50}$, half-maximal inhibitory concentration.

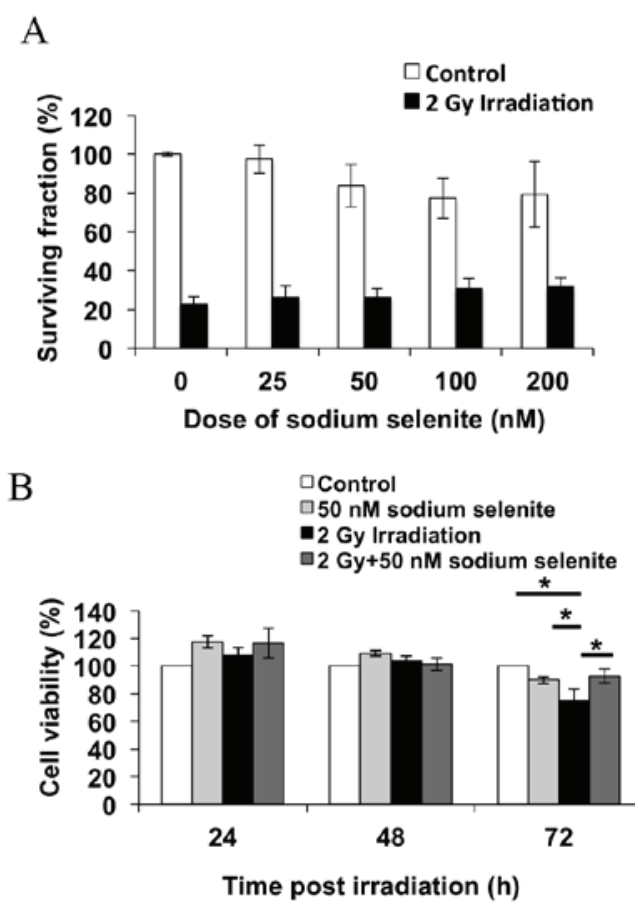

Figure 3. Post-irradiation CHEK-1 cell survival. (A) The surviving fractions of CHEK-1 cells, as determined by a colony formation assay, are presented; sodium selenite supplementation did not significantly increase the post-irradiation cell survival rate. Control groups did not undergo irradiation. (B) Post-irradiation CHEK-1 cell viability analysis revealed that sodium selenite supplementation increased the cell viability $72 \mathrm{~h}$ post-irradiation. The results are presented as the mean \pm standard error of the mean from three independent experiments. ${ }^{*} \mathrm{P}<0.05$. Gy, gray.

CHEK-1 cells with a $72 \mathrm{~h}$ incubation time, maximal GPx-1 activity was achieved. By examining various concentrations of sodium selenite with the same $72 \mathrm{~h}$ incubation time, GPx-1 activity was observed to become saturated at a concentration of $50 \mathrm{nM}$. Therefore, the sodium selenite dose that induced the highest GPx-1 activity was $50 \mathrm{nM}$ for $72 \mathrm{~h}$; these conditions were subsequently used for further experiments.

Cytotoxicity of sodium selenite in CHEK-1 cells. Fig. 2 depicts the cytotoxicity of sodium selenite in CHEK-1 cells based on the percentage of cell proliferation inhibition. The $\mathrm{IC}_{50}$ was determined to be $3.6 \mu \mathrm{M}$. The dose of $50 \mathrm{nM}$ sodium selenite was assumed to be a low and safe dose for supplementation for the cells, compared with the $\mathrm{IC}_{50}$ dose $(3.6 \mu \mathrm{M})$. In addition, using linear regression analysis, $50 \mathrm{nM}$ sodium selenite supplementation was estimated to inhibit $\leq 3 \%$ of cell proliferation.

Sodium selenite supplementation increases the post-irradiation cell survival rate. Post-irradiation survival of CHEK-1 cells was observed using a clonogenic assay and cell viability assay. Fig. 3A presents the colony formation of the cells at 14 days post-irradiation. Sodium selenite supplementation increased post-irradiation cell survival by increasing the percentage of surviving cells in a dose-dependent manner, though this trend was not statistically significant. Fig. 3B depicts cell viability at 24-72 h post-irradiation; at $72 \mathrm{~h}$ post-irradiation, the viability of the cells treated with $50 \mathrm{nM}$ sodium selenite and 2 Gy irradiation was increased, compared with 2 Gy irradiation alone $(\mathrm{P}=0.031)$. These results suggested that sodium selenite supplementation prior to irradiation protects the cells from irradiation-induced damage.

Sodium selenite supplementation reduces the proportion of sub-G1 phase cells post-irradiation. The cell cycle distribution of CHEK-1 cells post-irradiation is presented in Fig. 4. The percentages of cells observed to be in sub- $G_{1}, G_{1}, G_{2} / M$ and $S$ phases at $72 \mathrm{~h}$ in the untreated control groups were 2.7 \pm 0.03 , $71.2 \pm 5.01,22.5 \pm 1.03$ and $3.5 \pm 4.44 \%$, respectively, whereas these percentages for cells in the $50 \mathrm{nM}$ sodium selenite groups were $2.5 \pm 0.11,64.6 \pm 3.21,24.3 \pm 0.94$ and $8.6 \pm 2.85$, respectively. These results indicate that the cell cycle profile was not affected by treatment with sodium selenite, with the exception of a non-significant decrease in the number of $\mathrm{G}_{1}$ cells from 71.2 to $64.6 \%(\mathrm{P}=1.00)$ between the control and sodium selenite groups. Treatment with $2 \mathrm{~Gy} \mathrm{X}$-ray radiation increased the percentage of sub- $\mathrm{G}_{1}$ phase cells from 2.8 to $5.9 \%(\mathrm{P}=0.00087)$ and non-significantly decreased the percentage of $\mathrm{G}_{1}$ phase cells from 71.2 to $58.8 \%$ at $72 \mathrm{~h}$ post-irradiation $(\mathrm{P}=0.33)$. Combined treatment with $50 \mathrm{nM}$ sodium selenite and $2 \mathrm{~Gy}$ X-ray irradiation resulted in a reduced percentage of sub- $\mathrm{G}_{1}$ cells (4.2 vs. 5.9\%; $\mathrm{P}=0.0061)$ and a non-significant increase in the percentage of $\mathrm{G}_{1}$ cells (62.1 vs. $58.8 \%$; $\mathrm{P}=1.00)$ at $72 \mathrm{~h}$ post-irradiation, compared with 2 Gy X-ray irradiation alone. These results indicate that sodium selenite supplementation prior to irradiation may reduce the percentage of apoptotic and damaged cells, and promote entry into the $G_{1}$ phase following irradiation.

Protein expression levels of PARP, an apoptosis biomarker. The expression levels of PARP protein, a principal biomarker for apoptosis, were analyzed by western blotting $72 \mathrm{~h}$ post-irradiation. The expression levels of PARP and cleaved PARP proteins are depicted in Fig. 5. GAPDH protein was used as a loading control. Treatment of the CHEK-1 cells with 2 Gy X-ray radiation increased the expression levels of cleaved PARP post-irradiation ( $\mathrm{P}=0.0394)$. Additionally, combination treatment with $50 \mathrm{nM}$ sodium selenite and 2 Gy X-ray irradiation reduced the expression levels of cleaved PARP, as compared with irradiation alone; however, this difference was not statistically significant $(\mathrm{P}=0.423)$. These results indicate that sodium selenite may potentially inhibit radiation-induced apoptosis in non-cancerous cells. 
A
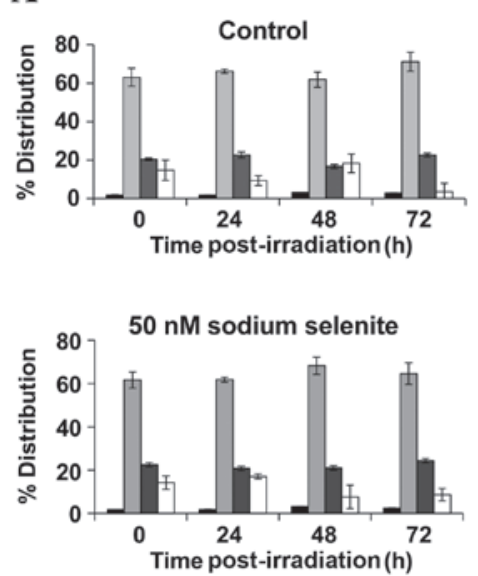

a Sub G1 घG1 घG2/M aS

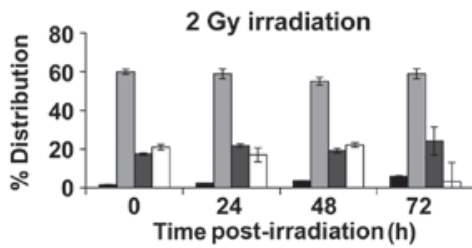

2 Gy irradiation $+50 \mathrm{nM}$

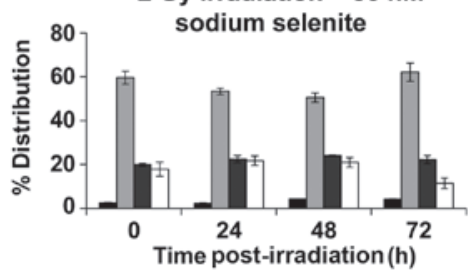

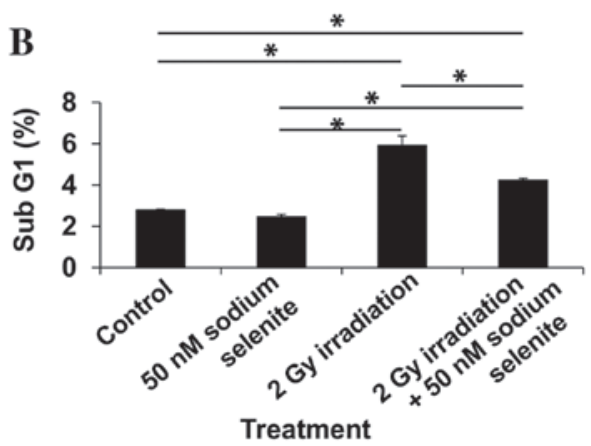

Figure 4. Cell cycle distribution of CHEK-1 cells post-irradiation. (A) The percentages of cells in sub- $\mathrm{G}_{1}, \mathrm{G}_{1}, \mathrm{G}_{2} / \mathrm{M}$ and $\mathrm{S}$ phases are presented. (B) The percentage of cells in the sub- $\mathrm{G}_{1}$ phase of the cell cycle at $72 \mathrm{~h}$ following $2 \mathrm{~Gy} \mathrm{X}$-ray irradiation are presented. The results are from three independent experiments and are presented as the mean \pm standard error of the mean. ${ }^{*} \mathrm{P}<0.05$. Gy, gray.

A $50 \mathrm{nM}$

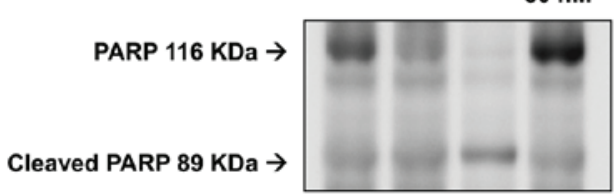

GAPDH $35 \mathrm{KDa} \rightarrow$

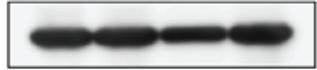

B

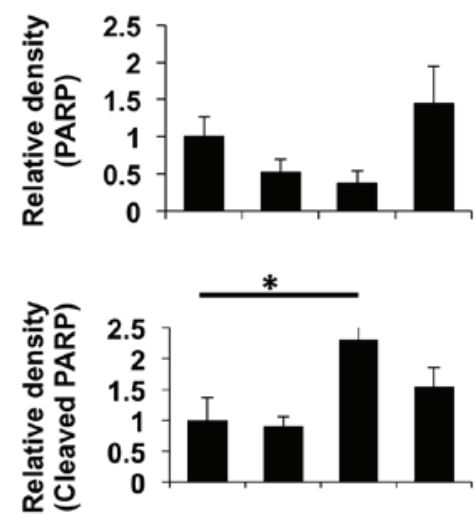

Figure 5. Protein expression levels of the apoptotic biomarker PARP. (A) Protein expression of PARP and cleaved PARP, and (B) the relative density of the bands normalized to GAPDH, are presented. The results are from three independent experiments and are presented as the mean \pm standard error of the mean. ${ }^{*} \mathrm{P}<0.05$. PARP, poly (ADP ribose) polymerase.

\section{Discussion}

The present study demonstrated that the supplementation of non-cancerous human esophageal cells with $50 \mathrm{nM}$ sodium selenite prior to radiotherapy may protect the cells from radiation-induced damage and that this protection may be due to the inhibition of radiation-induced apoptosis. These results are concordant with those of a previous study that used the organoselenium compound ebselen for the supplementation of U937 cells prior to irradiation treatment (18).

Irradiation kills not only tumor cells but also proliferating normal cells (2). Additionally, irradiation stimulates the production of ROS, which induce apoptotic cell death (26). One method of radioprotection involves the inhibition of caspase activation and PARP cleavage (2). PARP cleavage is often associated with apoptosis and caspase activation (27). By reducing the expression levels of cleaved PARP, which is potentially a molecular target for novel radioprotective compounds, sodium selenite supplementation may serve as a radioprotective compound for normal cells when administered prior to clinical radiotherapy.

GPx is an important enzyme of the cellular antioxidant defense systems that detoxify peroxides and hydroperoxides. Selenocysteine is present at the catalytic site of GPx and the availability of selenium regulates GPx enzyme activity (28). The stimulation of GPx activity following selenium supplementation indicates that the antioxidant function of this enzyme directly reduces the oxidative DNA damage 
associated with radiation exposure (16). The current study demonstrated that sodium selenite supplementation increases GPx-1 activity, which is concordant with a previous study by Diamond et al (16), indicating that the low-level supplementation of culture media with selenium, in the form of sodium selenite, markedly protected CHO-AA8 Chinese hamster ovary-derived cells from radiation-induced mutagenesis and that this protection was associated with a significant elevation in GPx-1 activity.

In conclusion, the present study investigated the protective effects of sodium selenite supplementation against irradiation-induced damage in non-cancerous esophageal cells. The results suggest that treatment with $50 \mathrm{nM}$ sodium selenite supplementation for $72 \mathrm{~h}$ prior to irradiation protects normal cells from irradiation-induced damage by inhibiting irradiation-induced apoptosis; therefore, sodium selenite may be a potential radioprotective compound for use in clinical radiotherapy. Husbeck et al (29) previously reported that alteration of the redox environment of prostate cancer cells by sodium selenite supplementation increased their apoptotic potential and sensitized them to radiation-induced cell death. However, further studies are required to fully elucidate the effects of sodium selenite supplementation on esophageal cancer cells.

\section{Acknowledgements}

This study was supported by an annual Dean Award grant in 2013 from Gunma University, Japan.

\section{References}

1. Shirazi A, Ghobadi G and Ghazi-Khansari M: A radiobiological review on melatonin: A novel radioprotector. J Radiat Res 48: 263-272, 2007.

2. Greenberger JS: Radioprotection: In Vivo 23: 323-336, 2009.

3. Nair CK, Parida DK and Nomura T: Radioprotectors in radiotherapy. J Radiat Res 42: 21-37, 2001.

4. Dörr W: Effects of selenium on radiation responses of tumor cells and tissue. Strahlenther Onkol 182: 693-695, 2006.

5. Weiss JF and Landauer MR: Radioprotection by antioxidants. Ann N Y Acad Sci 899: 44-60, 2000.

6. Rayman MP: The importance of selenium to human health. Lancet 356: 233-241, 2000.

7. Puspitasari IM, Abdulah R, Yamazaki C, Kameo S, Nakano T and Koyama H: Updates on clinical studies of selenium supplementation in radiotherapy. Radiat Oncol 9: 125, 2014.

8. Rayman MP: Selenium in cancer prevention: A review of the evidence and mechanism of action. Proc Nutr Soc 64: 527-542, 2005.

9. Fritz H, Kennedy D, Fergusson D, Fernandes R, Cooley K, Seely A, Sagar S, Wong R and Seely D: Selenium and lung cancer: A systematic review and meta analysis. PLoS One 6: e26259, 2011.

10. Abdulah R, Miyazaki K, Nakazawa M and Koyama H: Chemical forms of selenium for cancer prevention. J Trace Elem Med Biol 19: 141-150, 2005.
11. Ponholzer A, Struhal G and Madersbacher S: Frequent use of complementary medicine by prostate cancer patients. Eur Urol 43: 604-608, 2003.

12. Micke O, Buntzel J, Kisters K, Schafer U, Micke P and Mucke R: Complementary and alternative medicine in lung cancer patients: A neglected phenomenon? Front Radiat Ther Oncol 42: 198-205, 2010.

13. Schleicher UM, Lopez Cotarelo C, Andreopoulos D, Handt S and Ammon J: Radioprotection of human endothelial cells by sodium selenite. Med Klin (Munich) 94: (Suppl 3) 35-38, 1999 (In German).

14. Rodemann HP, Hehr T and Bamberg M: Relevance of the radioprotective effect of sodium selenite. Med Klin (Munich) 94: (Suppl 3) 39-41, 1999 (In German).

15. Micke O, Schomburg L, Buentzel J, Kisters K and Muecke R: Selenium in oncology: From chemistry to clinics. Molecules 14: 3975-3988, 2009.

16. Diamond AM, Dale P, Murray JL and Grdina DJ: The inhibition of radiation-induced mutagenesis by the combined effects of selenium and the aminothiol WR-1065. Mutat Res 356: 147-154, 1996.

17. Eckers JC, Kalen AL, Xiao W, Sarsour EH and Goswami PC: Selenoprotein $\mathrm{P}$ inhibits radiation-induced late reactive oxygen species accumulation and normal cell injury. Int J Radiat Oncol Biol Phys 87: 619-625, 2013.

18. Tak JK and Park JW: The use of ebselen for radioprotection in cultured cells and mice. Free Radic Biol Med 46: 1177-1185, 2009.

19. Abdulah R, Faried A, Kobayashi K, Yamazaki C, Suradji EW, Ito K, Suzuki K, Murakami M, Kuwano $\mathrm{H}$ and Koyama H: Selenium enrichment of broccoli sprout extract increases chemosensitivity and apoptosis of LNCaP prostate cancer cells. BMC Cancer 9: 414, 2009

20. Lowry OH, Rosebrough NJ, Farr AL and Randall RJ: Protein measurement with the Folin phenol reagent. J Biol Chem 193: 265-275, 1951.

21. Paglia DE and Valentine WN: Studies on the quantitative and qualitative characterization of erythrocyte glutathione peroxidase. J Lab Clin Med 70: 158-169, 1967.

22. Buch K, Peters T, Nawroth T, Sänger M, Schmidberger H and Langguth P: Determination of cell survival after irradiation via clonogenic assay versus multiple MTT Assay-a comparative study. Radiat Oncol 7: 1, 2012.

23. Franken NA, Rodermond HM, Stap J, Haveman J and van Bree C: Clonogenic assay of cells in vitro. Nat Protoc 1: 2315-2319, 2006.

24. Kanda Y: Investigation of the freely available easy-to-use software 'EZR' for medical statistics. Bone Marrow Transplant 48: 452-458, 2013.

25. Rafferty TS, Green MH, Lowe JE, Arlett C, Hunter JA, Beckett GJ and McKenzie RC: Effects of selenium compounds on induction of DNA damage by broadband ultraviolet radiation in human keratinocytes. Br J Dermatol 148: 1001-1019, 2003.

26. Lee JH, Kim SY, Kil IS and Park JW: Regulation of ionizing radiation-induced apoptosis by mitochondrial NADP+-dependent isocitrate dehydrogenase. J Biol Chem 282: 13385-13341, 2007.

27. Yang Y, Zhao S and Song J: Caspase-dependent apoptosis and -independent poly(ADP-ribose) polymerase cleavage induced by transforming growth factor beta1. Int J Biochem Cell Biol 36: 223-234, 2004.

28. Baker RD, Baker SS, LaRosa K, Whitney C and Newburger PE: Selenium regulation of glutathione peroxidase in human hepatoma cell line Hep3B. Arch Biochem Biophys 304: 53-57, 1993.

29. Husbeck B, Peehl DM and Knox SJ: Redox modulation of human prostate carcinoma cells by selenite increases radiation-induced cell killing. Free Radic Biol Med 38: 50-57, 2005. 